\title{
SOEP
}

SOEPpapers

SOEPpapers
on Multidisciplinary Panel Data Research

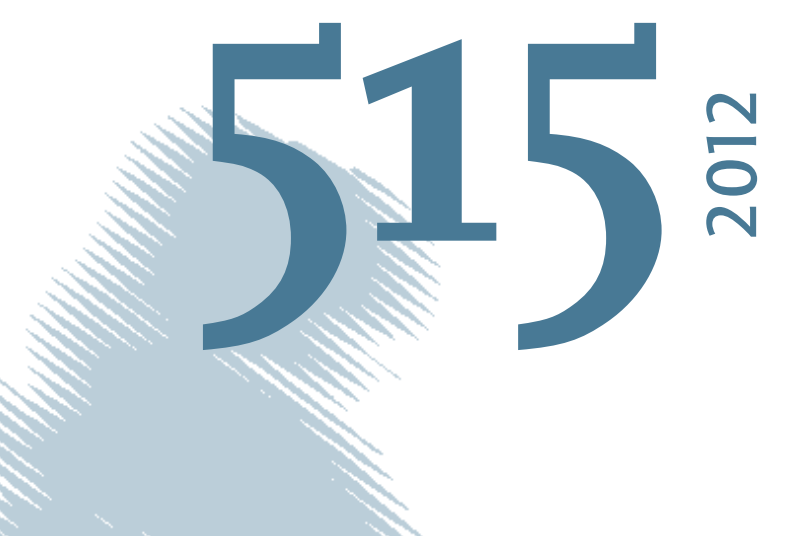

Wh

\section{Offshoring and labor income risk: an empirical investigation}

Jan Hogrefe and Yao Yao 


\section{SOEPpapers on Multidisciplinary Panel Data Research}

at DIW Berlin

This series presents research findings based either directly on data from the German SocioEconomic Panel Study (SOEP) or using SOEP data as part of an internationally comparable data set (e.g. CNEF, ECHP, LIS, LWS, CHER/PACO). SOEP is a truly multidisciplinary household panel study covering a wide range of social and behavioral sciences: economics, sociology, psychology, survey methodology, econometrics and applied statistics, educational science, political science, public health, behavioral genetics, demography, geography, and sport science.

The decision to publish a submission in SOEPpapers is made by a board of editors chosen by the DIW Berlin to represent the wide range of disciplines covered by SOEP. There is no external referee process and papers are either accepted or rejected without revision. Papers appear in this series as works in progress and may also appear elsewhere. They often represent preliminary studies and are circulated to encourage discussion. Citation of such a paper should account for its provisional character. A revised version may be requested from the author directly.

Any opinions expressed in this series are those of the author(s) and not those of DIW Berlin. Research disseminated by DIW Berlin may include views on public policy issues, but the institute itself takes no institutional policy positions.

The SOEPpapers are available at

http://www.diw.de/soeppapers

\section{Editors:}

Jürgen Schupp (Sociology, Vice Dean DIW Graduate Center)

Gert G. Wagner (Social Sciences)

Conchita D'Ambrosio (Public Economics)

Denis Gerstorf (Psychology, DIW Research Director)

Elke Holst (Gender Studies, DIW Research Director)

Frauke Kreuter (Survey Methodology, DIW Research Professor)

Martin Kroh (Political Science and Survey Methodology)

Frieder R. Lang (Psychology, DIW Research Professor)

Henning Lohmann (Sociology, DIW Research Professor)

Jörg-Peter Schräpler (Survey Methodology, DIW Research Professor)

Thomas Siedler (Empirical Economics)

C. Katharina Spieß (Empirical Economics and Educational Science)

ISSN: 1864-6689 (online)

German Socio-Economic Panel Study (SOEP)

DIW Berlin

Mohrenstrasse 58

10117 Berlin, Germany

Contact: Uta Rahmann | soeppapers@diw.de 


\title{
Offshoring and labor income risk: an empirical investigation ${ }^{\dagger}$
}

\author{
Jan Hogrefe* \\ Yao Yao $\ddagger$ \\ ZEW Mannheim \\ Mannheim University \\ University of Tuebingen
}

\begin{abstract}
This paper analyses how increased offshoring impacts on labor income risk. It is therefore distinct from a large number of studies explaining the level effects of globalization on the labor market in that it takes a look at effects on the variability of incomes. It provides an assessment that directly connects labor income risk and offshoring trends in a panel setting at the industry level. Importantly, we distinguish between transitory and permanent shocks to individual income. Permanent income risk is defined as variance of shocks to income that do not fade out over time. Contrary to transitory short-term fluctuations, it is furthermore assumed to be uninsurable. It thus has a particular relevance for individual welfare. Our findings suggest that offshoring tends to lower permanent income risk. This effect is particularly strong for offshoring to low-income destinations. Hence, there could be potential aggregate welfare gains when domestic firms increasingly offshore production to foreign countries.
\end{abstract}

Keywords: globalization, offshoring, labor income risk, wages

JEL: F16, F23, E24

\footnotetext{
${ }^{\dagger}$ For valuable comments and suggestions, the authors would like to thank Sebastian Benz, Gabriel Felbermayr, Marcus Kappler, Tom Krebs, Wilhelm Kohler, and Atilim Seymen as well as participants at the ETSG 2011, DMM 2011, SMYE 2011 conferences and seminars and workshops in Mannheim, Munich, Goettingen, and Tuebingen. All potential errors are our own.

${ }^{*}$ Corresponding author. Centre for European Economic Research (ZEW), L7 1, 68161 Mannheim, Germany, e-mail: hogrefe@zew.de, phone +49 (0) 6211235348

${ }^{\ddagger}$ Department of Economics, Mannheim University, L7 3-5, 68161 Mannheim, Germany, email: yao.yao@unimannheim.de
} 


\section{Introduction}

Globalization is often perceived as creating a more volatile working environment on the labor market. In particular, trends such as the relocation of parts of production abroad (offshoring) induce fears of job loss and higher fluctuations in individual income. While the long-run level effects of different types of offshoring on income and employment have been documented by a large literature, see e.g. Feenstra (2010), a lot less academic attention has been paid to the analysis of effects on the variability of incomes. Our paper further completes the picture of how offshoring has an impact on characteristics of labor income by estimating its relationship to income risk with data from German manufacturing. To the best of our knowledge, our paper is the first to put the link between offshoring and income risk at the heart of an empirical analysis.

Income risk is defined as the variance of changes in the unexplained component of individual income. As such, it describes changes in income that are not a result of observable and predictable characteristics like age or education. Crucially, and in line with the literature, we econometrically distinguish between transitory and permanent risks to income. Transitory shocks to income are more likely to be smoothed out by self-insurance mechanisms such as saving and borrowing. However, this does not hold for permanent shocks, i.e. shocks that permanently shift an individual's income trajectory. Following the literature, we assume permanent income risk to be uninsurable from an individual perspective. Then, unexpected permanent variation in income affects the present value of lifetime earnings, which impacts on individual welfare (Aiyagari 1994). It is thus the permanent component of income shocks we are interested in. Linking offshoring to changes in the variance of permanent income shocks yields evidence on the effect of offshoring on labor income which allows for considerations on welfare consequences.

Our analysis proceeds in several steps. First, we derive and estimate measures of income risk which we subsequently link to offshoring. We provide two variants of the analysis. We begin our effort by taking a long-run perspective and estimate the permanent component of income risk from the German Socio-Economic Panel (SOEP). Here, income risk is estimated at the industry level from individual income data as the average variance of changes in the unex- 
plained component of individual income. The latter is retrieved from standard Mincerian wage regressions. Based on this data, we uncover average income risk over five-year intervals which we link to average offshoring intensities at the industry level in a panel setting. We therefore aim at answering whether a structural change in the economy, with ever more production stages being performed abroad, leads to domestically higher or lower income risk. Subsequently, we turn to a yearly analysis. At this stage we use individual-level data from official German social security records to estimate industry level income risk, allowing us to link offshoring and income risk at a higher frequency. Both approaches rely on panel methods, helping us to answer the question of whether an increase in offshoring over time increases or decreases income risk. The offshoring measures are calculated at the industry level in a way similar to Feenstra \& Hanson (1996). We use detailed yearly import matrices from input-output tables in combination with output and trade data.

From the outset, it is not clear whether offshoring increases or decreases income risk - especially with respect to the permanent component. On the one hand, there is empirical evidence at the industry-level that offshoring tends to raise labor demand elasticities which could lead to higher income risk, e.g. (Senses 2010). On the other hand, this evidence is in part contradicted at finer levels of aggregation. Becker \& Muendler (2008) find offshoring to actually lower separation rates in employment at the firm-level and Buch \& Lipponer (2010) directly cast doubt on the claim that offshoring is responsible for changes in labor demand elasticities within multinational firms. It is important to note, however, that most studies within the rather inconclusive empirical literature are only indirectly related to the concept of income risk, and its permanent component in particular. As mentioned above, our analysis specifically tries to address a measure of "insecurity" that has clear and well-documented welfare implications - a characteristic generally attributed to the permanent component of income risk.

In addition to the mixed empirical results, theory recently suggested offshoring to be much less of a specter to workers than what is reflected in public anxiety and job loss fears. For example, Bergin et al. (2009) show that offshoring has the potential to exert a dampening effect 
on economic volatility in the offshoring country if demand shocks are buffered by excess production activity in offshore plants. In other words, fluctuations are "exported" and firms face a less volatile domestic economic environment; and potentially their workers do as well. ${ }^{1}$ It is also possible that offshoring induces what may be called a "composition effect". If offshoring is understood as trade in tasks, as in Grossman \& Rossi-Hansberg (2008), and the tasks as such differ in their specific income volatilities, the relocation of certain tasks abroad might lead to aggregate changes in industry-level income risk. If the offshored tasks are at the same time more volatile with respect to income, the average income risk of the tasks remaining onshore falls. One could think of this effect as arising from firms effectively insuring themselves against fluctuations in economic activity. If institutional rigidities in the home market make adjustment costly, firms would be expected to relocate the activities most affected in places where adjustment is less costly. Such considerations seem particularly plausible in light of the European Union's enlargement to the East and Germany's location close to the new EU member states. ${ }^{2}$

The particular focus on offshoring also sets this paper apart from the recent literature studying effects on income risk arising from other forms of globalization such as import competition and tariff reductions. Krebs et al. (2010) analyse how tariff reductions and the ensuing integration of the Mexican economy into the world market (in particular the North American part of it) affected income risk. They show income risk to increase as a response to trade liberalization, inducing the emergence of negative welfare effects. Yet, the Mexican economy may be considered a rather special case, in particular with regard to its proximity to the US and the existence of the "maquiladora" sector near the northern border. ${ }^{3}$ Krishna \& Senses (2009) set out to find the roots of income risk for the US labor market. Their prime candidate is import competition, which they show to raise the permanent component of income risk. ${ }^{4}$ We focus on offshoring to

\footnotetext{
${ }^{1}$ Yet, the opposite holds true for the receiving country. Volatility abroad (e.g. in Mexico for the case of US offshoring) is amplified.

${ }^{2}$ Note that this does not necessarily lead to an aggregate employment loss with less volatile yet lower overall employment at home since offshoring also triggers productivity effects possibly leading to net job creation (Kohler \& Wrona 2010).

${ }^{3}$ In fact, this "maquiladora" sector has been shown in Bergin et al. (2009) to have a particularly high volatility due to its role in the production sharing with the US economy.

${ }^{4}$ As a robustness check, which consists of including a host of further variables, these authors also employ an offshoring variable which shows a negative coefficient in their estimations. However, this variable differs in its
} 
explicitly contrast the concerns about increased risks often raised in the public debate with the potentially risk smoothing effects of a more efficient international allocation of production tasks.

Our findings contradict the general impression of offshoring as a major factor in raising longrun income volatility. They suggest an increase in offshoring is significantly correlated with a decrease in the permanent component of income risk at the industry level. The observed rise in the overall offshoring intensity implies, on average, a $11 \%$ to $28 \%$ fall in permanent income risk compared to its mean value. For offshoring to non-OECD countries, the corresponding numbers for the observed increase reach up to around 30\%. Looking at offshoring as a particular type of international trade, we thus find the opposite effect in comparison with other studies relating more general measures of globalization to permanent income risk.

The paper is structured as follows. The next section details the approach for estimating income risk, presents the data we use, and gives further insight into measuring the offshoring intensity at the industry level. In sections 3 and 4 we describe in detail the econometric specification and provide results on how income risk is affected by offshoring, respectively. A concluding section features some important considerations on welfare effects.

\section{Estimation and calculation of variables}

\subsection{Estimating labor income risk}

The approach taken in this paper involves a three-stage procedure to first estimate the permanent component of individual income risk (stage one and two), and then relating these to carefully constructed offshoring indices at the industry level (stage three). The goal of this section is to motivate our measure of income risk and to derive the corresponding estimation procedure. We follow the bulk of the literature and define income risk as the unpredictability of individual income while referring to this variability from an ex-ante perspective, see Carroll \& Samwick (1997); Meghir \& Pistaferri (2004), among others. As such, income risk accompanies construction from the ones used here and its impact is not further discussed by the authors. 
people whenever their future income is stochastic. In this sense, income risk is conceptualized as a deviation of the future income stream from its expectation, and is estimated as the variance of changes in the unexpected component of individual income.

In our paper, as in most of the related literature, the estimated income risk has two components: transitory income risk and permanent income risk. This distinction is important since the two components have vastly different welfare effects. Transitory risk refers to the variance of stochastic income changes without persistence. Therefore, it could be effectively "self-insured" by individuals through saving and borrowing. Such unexpected transitory variation could be introduced by windfall labor income or changes in hours worked, which do not persist until the end of an individual's working life. Thus, following common theoretical considerations, there are no reasons for individuals to change their consumption and savings pattern, and therefore there are hardly any welfare effects (Levine \& Zame 2002). For the permanent component of income shocks, however, a different picture emerges. Permanent income risk has profound effects on the consumption-savings decision of individuals in environments with imperfect insurance possibilities. Permanent income shocks reflect the stochastic trend of income. These shocks have persistent power over the remaining working period of individuals. This affects the present value of lifetime earnings and thus individuals consume out a certain amount of permanent shocks. Therefore, and in contrast to transitory risk, permanent income risk has a direct effect on individual welfare (Constantinides \& Duffie 1996, Krebs 2003). Permanent shocks are observed as permanent events during workers' employment - for example, promotion beyond expectation or changes in employment resulting in a different matching quality of an individual's abilities and the job's requirements. Given its welfare relevance, we thus focus our analysis on the connection between offshoring and permanent labor income risk. Following related studies, we disregard the transitory component. ${ }^{5}$

The procedure for estimating the components of income risk starts with the identification of the unexplained component of individual income. This component is retrieved as the residual

\footnotetext{
${ }^{5}$ Another reason for ignoring transitory income risk is that this measure will pick up all measurement error in the estimation procedure outlined below (Krebs et al. 2010).
} 
from standard Mincerian wage regressions of the following form:

$$
y_{i t}=\alpha_{j t}+\beta_{t} X_{i j t}+u_{i j t}
$$

Note that the regressions are run year-by-year and include fixed-effects for industries $j$. The control vector $X_{i j t}$ includes the commonly used wage determinants such as age, education, marital status, nationality and firm-size. ${ }^{6}$ Notice that the estimation allows for changes in the returns to observable characteristics. An increase in the skill premium, for instance, is not regarded as contributing to income risk. The regressions are run on a restricted sample which includes individuals fully employed in manufacturing industries in West Germany. $y_{i t}$ is the natural logarithm of our income variable for individual $i$ in year $t$, specified in more detail in the database descriptions below. The above model implies that individuals derive their expectations about the future income from a projection based upon their observable and predictable characteristics. Thus, $u_{i j t}$ is the unexpected and stochastic component of individual earnings, which is idiosyncratic and unpredictable to them. We show exemplary results from this first stage regression in the appendix.

For the estimation of income risk and its components we make the following assumptions. Suppose $u_{i j t}$ has two components: a permanent one $\omega_{i j t}$ and a transitory one $\epsilon_{i j t}$. Furthermore, assume $\omega_{i t}$ to follow a random walk process. ${ }^{7}$

$$
\begin{gathered}
u_{i j t}=\omega_{i j t}+\epsilon_{i j t} \\
\omega_{i j t}=\omega_{i j t-1}+\eta_{i j t}
\end{gathered}
$$

In equation (2), $\epsilon_{i j t}$ is white noise, which has only a temporary effect on labor income and

\footnotetext{
${ }^{6}$ In the SOEP data, due to the lower number of observations at our disposal, we include both male and female individuals and add a corresponding dummy variable to the control vector. In the BA data, we focus on male individuals since they are usually assumed to be the household head with their income being less affected by intra-household labor substitution.

${ }^{7}$ The random walk assumption is not the only possible structure underlying the income process. For instance, other papers have suggested including a third, MA(1), component. Yet, it has been shown that the permanent component of income risk is hardly affected by different assumptions on the income process. We therefore stick to the random walk assumption.
} 
would vanish in the next time period. $\eta_{i j t}$, however, has persistence because $\omega_{i j t}$ follows a random walk process.

Based on this assumed structure of the unexplained part of income, we can single out the permanent component of income risk. Recall that we are interested in the variance of the changes in this unexplained part of income. There are two different strategies usually employed in the literature. They differ in their assumptions of whether income risk can be assumed to be timeindependent. As can be seen from the following subsections, assuming time-independence (at least within sub-periods) substantially simplifies the estimation. We will nevertheless calculate both time-invariant and year-specific income risk. However, we will have to use different data sources in the two cases.

\subsubsection{Time-invariant income risks}

In this subsection, we assume that shocks are time-invariant, that is, $\epsilon_{i t}$ and $\eta_{i t}$ in each period are white noise and i.i.d distributed. ${ }^{8}$

$$
\begin{aligned}
& \epsilon_{i t} \sim N\left(0, \sigma_{\epsilon}^{2}\right) \\
& \eta_{i t} \sim N\left(0, \sigma_{\eta}^{2}\right)
\end{aligned}
$$

$\epsilon_{i t}$ and $\eta_{i t}$ are independent for all leads and lags, that is, $\operatorname{cov}\left(\epsilon_{i t}, \epsilon_{i s}\right)=0, \forall t \neq s, \operatorname{cov}\left(\eta_{i t}, \eta_{i s}\right)=$ $0, \forall t \neq s, \operatorname{cov}\left(\epsilon_{i t}, \eta_{i s}\right)=0, \forall t, s$. For the changes in the unexplained income over time, we can generally write the n-year difference of $u_{i t}$ as

$$
\triangle_{n} u_{i t}=u_{i t+n}-u_{i t}=\eta_{i t+1}+\ldots+\eta_{i t+n}+\epsilon_{i t+n}-\epsilon_{i t}
$$

Hence, assuming $\eta_{i}=\eta_{i t}$ the variance of $\triangle_{n} u_{i t}$ is simply given by:

$$
V\left[\triangle_{n} u_{i}\right]=n \sigma_{\eta}^{2}+2 \sigma_{\epsilon}^{2}
$$

\footnotetext{
${ }^{8}$ In this section we drop the subscript $j$ to improve on the exposition. Naturally, all income risk measures estimated and used in the analysis in further sections are to be understood as industry-level variables.
} 
where $\sigma_{\epsilon}^{2}$ and $\sigma_{\eta}^{2}$ are the variances of the transitory and permanent shocks to income, respectively. Note that $2 \sigma_{\epsilon}^{2}$ is a constant. Thus, the simplifying assumption of time-invariant income risk allows us to retrieve $\hat{\sigma}_{\eta}^{2}$ from a simple linear regression. ${ }^{9}$ This is the approach taken by the vast majority of the literature on the estimation of income risk (see for example Gottschalk \& Moffitt (1994); Carroll \& Samwick (1997); Krishna \& Senses (2009)). Note that with a sufficiently large $T$, it is possible to still retrieve quasi time-varying coefficients for income risk if time-independence is assumed to hold within but not between subperiods $m$. This is the approach we follow for part of the analysis in this paper where we assume income risk to be constant within 5 year sub-periods.

\subsubsection{Time-specific income risks}

The above assumption of time-independence may seem to be a strong one, and the quick-fix solution of looking at changes in permanent income risk between subperiods somewhat arbitrarily rests on the choice of the length of $m$. Shocks to permanent labor income in reality could differ across time periods due to, e.g. macroeconomic factors such as business cycle movements or trade related influences. ${ }^{10}$ In fact, this is exactly what our paper is aiming to identify: How changes in permanent income risk can be explained. We therefore briefly describe the adjustments needed for estimation of yearly values of permanent income risk.

Dropping the assumption of time-constancy of income risk, $\epsilon_{i t}$ and $\eta_{i t}$ are no more i.i.d normally distributed in each period, but dependent on time, that is,

$$
\begin{aligned}
\epsilon_{i t} & \sim N\left(0, \sigma_{\epsilon t}^{2}\right) \\
\eta_{i t} & \sim N\left(0, \sigma_{\eta t}^{2}\right)
\end{aligned}
$$

Still, $\epsilon_{i t}$ and $\eta_{i t}$ are independent with each other at all leads and lags. $\operatorname{cov}\left(\epsilon_{i t}, \epsilon_{i s}\right)=0, \forall t \neq$ $s, \operatorname{cov}\left(\eta_{i t}, \eta_{i s}\right)=0, \forall t \neq s, \operatorname{cov}\left(\eta_{i t}, \epsilon_{i s}\right)=0, \forall t, s$.

\footnotetext{
${ }^{9}$ In more detail, we minimize $\sum_{t} \sum_{1}^{T-t}\left[V\left[\triangle_{n} u_{i t}\right]-\left(n \sigma_{\eta}^{2}+2 \sigma_{\epsilon}^{2}\right)\right]^{2}$ by using OLS methods.

${ }^{10}$ Storesletten et al. (2004) argue that the conditional variance of these permanent income shocks is countercyclical, increasing during contractions and decreasing during expansions. Krebs et al. (2010) find that trade policy has a significant effect on income risk.
} 
In contrast to (7) above, the variance of changes in the unexplained component of individual income between period $t$ and $t+n$ now is given by:

$$
V\left[\triangle_{n} u_{i t+n}\right]=\sigma_{\eta, t+1}^{2}+\ldots+\sigma_{\eta, t+n}^{2}+\sigma_{\epsilon, t}^{2}+\sigma_{\epsilon, t+n}^{2}
$$

The estimation furthermore relies on additional moment conditions for the transitory component. In particular, it is assumed that this component of income risk is identical for the first and last two periods. Naturally, this also restricts the permanent component to being the same for those periods. According to Krebs et al. (2010), the permanent component of income risk can be estimated from (10) using GMM methods. In particular, given the relatively small sample size of our available data, we use the equally weighted minimum distance (EWMD) estimator as this is superior to a two-step GMM approach using the optimal weighting matrix once small sample bias is taken into account (Altonji \& Segal 1996).

\subsection{Data and implementation}

In order to implement the above estimation strategy, our data has to meet certain requirements. On the one hand, we need a sufficient amount of variation within each industry for each year. On the other hand, it is desirable to have a long time dimension in order to track the relationship of offshoring and income risk for several years. We have two different data sets at our disposal, each of which has its particular advantages. The first data set is a long-run survey, the so-called German Socio-Economic Panel (SOEP). ${ }^{11}$ The second is a sample from official social security records from the German Employment Agency ("BA-Employment panel"). ${ }^{12}$

In both cases we use information on income for individuals that stay within the same 2-digit industry over time. ${ }^{13}$ We thus predominantly observe income variation for people who remain

\footnotetext{
${ }^{11}$ The SOEP data are provided by the DIW Institute in Berlin. Information on variables and data access can be found in Wagner et al. (2007) and at http://ww.diw.de/en/diw_02.c.222724.en/soepinfo.html

${ }^{12}$ This study uses the factually anonymous BA-Employment Panel (Years 1998 - 2007). Data access was provided via a Scientific Use File supplied by the Research Data Centre (FDZ) of the German Federal Employment Agency (BA) at the Institute for Employment Research (IAB). For detailed information on the database, see Schmucker \& Seth (2009).

${ }^{13}$ About $87.25 \%$ of observed individuals stay within the same 2-digit industry.
} 
employed, yet face income changes due to wage changes and changes in other payments such as bonuses. Yet, we do not exclude individuals that lose their job once or several times as long as they are re-employed in the same industry at some point in our sample, irrespective of how long the unemployment spell is. In fact, temporary job loss is likely an important source of variation in income as job transition is often accompanied by a loss of occupation or employer-specific human capital leading to persistent changes in income. If an individual is employed in several industries over the sample period, we treat it as if it were two different individuals. That is, we use variation occurring during employment within an industry, but not between industries. We thus do not include variation based on individuals switching between industries or out of manufacturing in general. We admit that switching industries can be a source of income risk, yet one that is difficult to assign to any industry's aggregate income risk. This also makes it impossible to link it to industry-level offshoring in our framework. ${ }^{14}$ Even within these limits, we will show that there is considerable variation in individual income and that a substantial part of this is reflected in permanent income risk.

While the SOEP data covers individuals since the mid-1980s and therefore allows for a longer-run view on income risk, it has insufficient observations by year and industry to fully estimate time-varying income risk. We therefore divide this data into 5-year sub-periods and estimate the permanent component of income risk based on (7) within each one of them. Thus, we assume that the transitory and permanent components can change between periods, but are constant within each 5-year period. That is, $\epsilon_{i t} \sim N\left(0, \sigma_{\epsilon, m}^{2}\right), \eta_{i t} \sim N\left(0, \sigma_{\eta, m}^{2}\right)$.

The wage regressions are run on a sample restricted to west German residents aged 18 to 65 that are fully employed in one of the 22 two-digit NACE manufacturing industries. The income variable in this case is the log-hourly wage rate, for which we set a threshold at the minimum social security transfer payment in order to exclude individuals who report implausibly low labor income. We also adjust for oversampling of high income individuals.

\footnotetext{
${ }^{14}$ Krishna \& Senses (2009) estimate income risk to be higher for individuals experiencing a transition from one industry to another when compared to individuals staying in one industry. We thus regard our estimations of income risk as representing a lower bound. On the difficulty of including this variation in a study exploring the causes for changes in income risk, also see (Krebs et al. 2010).
} 
In contrast to the SOEP, the BA-Panel is rather short with its 10 year time period. Yet, it has significantly more observations per industry and year. Thus, it allows us to estimate yearly income risk. It represents a 2 percent random sample drawn from official German employment records based on social security contributions for the years from 1998 to 2007. Income information in this case is log-monthly income and includes non-wage payments such as bonuses to the employees. Again, we restrict the panel to full-time employed, working age, West German residents. This still leaves us with a total of more than 770,000 individual observations. We then proceed by applying the estimation approach for time-varying income risk. Note that our focus on permanent income implies that we only obtain estimates for the years up to 2005, since persistence of shocks is hardly observed when approaching the last year of sample. Furthermore our estimation approach technically relies on the additional assumption that in the first two periods, income risk values are identical. This leaves us with observations for the years 1999 to 2005 .

A common concern about such official German employment records is that the accompanying income information is censored at the legal threshold for social security contributions. This is the case in the present data as well. It is of potential concern that some income variation might be precluded from the analysis. Note that even an approach as ours, which relies on variation over time between industries when linking offshoring and income risk, is affected since the share of individuals at the income threshold is non-constant. On the other hand, the problem is less severe in manufacturing and in particular among low-skilled workers. These individuals simply rarely reach the threshold income. Yet, we tackle the problem, as most studies in the literature, e.g. (Dustmann et al. 2009), by imputing the censored part of the wage distribution. We follow Gartner (2005) and use an approach based on truncated regressions and draws from a log-normal distribution. ${ }^{15}$

Finally, the BA-panel data is quarterly in its original style. Yet, most of the income information is based on one entry per year only (so called "Jahresmeldung"). Thus, only yearly information can be calculated. We do so by using time-weighted averages over all reported

\footnotetext{
${ }^{15}$ Note that censoring of the wage variable plays no role in the SOEP as this is survey data.
} 
monthly income data points as long as the individual does not change the industry of employment within the year. ${ }^{16}$

\subsection{Income risk: results}

Table 1 shows estimates of the permanent component of income risk based on the SOEP data. ${ }^{17}$ It can be seen that the estimates vary quite a bit across industries, both with respect to levels and the change from the first to the last period. ${ }^{18}$ The estimates imply an employment weighted average standard deviation of 0.077 . That implies an average (permanent) yearly change of $8 \%$ of the residual hourly wage rate.

In table 2, we present results derived from the more detailed BA-panel. Again, we see some heterogeneity across industries. The estimates are similar, yet a bit lower than the ones in table 1. The employment weighted average risk to residual monthly wages stands at around $6 \%$. The differences in the estimated values for permanent income risk stem mainly from the use of different data. In particular, income risk estimates are usually sensitive to sample length. More importantly, we do not rely on level values in our estimations below. Instead we estimate the effect using fixed-effect methods in a panel setting.

The above estimates are somewhat lower than those found in other studies, e.g. (Krebs et al. 2010). Note, however, that this latter study, as well as others, overestimates permanent income risk since it assumes all remaining income variation after 4 quarters to be permanent, whereas we treat changes from one year to the next as transitory still. Furthermore, some studies rely on total household income which inherently has higher risk since it includes the outcomes of labor-leisure choice and substitution effects between household members. Additionally, it is

\footnotetext{
${ }^{16}$ We also provide estimates based on just using information from a single wave per year; the June wave in our case. This more restrictive alternative yields estimates that are qualitatively very similar to results detailed below and are shown in the appendix.

${ }^{17}$ Since our offshoring data is for the years after 1991 only, we do not show income risk estimates prior to 1991.

${ }^{18}$ Note that for industry 36 , the estimate is negative which is unrealistic since a variance is by definition a positive value. This estimate, as well a few others, is not statistically significant, however. We will show later on that exclusion of the few insignificant income risk estimates does not alter much our estimates of the influence of offshoring on income risk.
} 
plausible that by international standards the German labor market features lower income risk due to stronger institutions such as employment protection and wage bargaining coordination.

Table 1: Descriptives: income risk, SOEP

\begin{tabular}{lrrrr}
\hline Industry & Code & $\hat{\sigma}_{\eta, j}^{2}$ & $\hat{\sigma}_{\eta, j}$ & Change $\left(\hat{\sigma}_{\eta, j}^{2}\right)$ \\
\hline Food Products And Beverages & 15 & 0.0080 & 0.0896 & 0.0103 \\
Tobacco Products & 16 & 0.0301 & 0.1736 & -0.0022 \\
Textiles & 17 & 0.0044 & 0.0661 & 0.0027 \\
Wearing Apparel; Dressing And Dyeing & 18 & 0.0074 & 0.0859 & -0.0048 \\
Tanning,Dressing Of Leather; luggage & 19 & 0.0376 & 0.1940 & 0.0210 \\
Wood Products, Except Furniture & 20 & 0.0012 & 0.0347 & -0.0010 \\
Pulp, Paper And Paper Products & 21 & 0.0081 & 0.0901 & 0.0116 \\
Publishing, Printing And Reproduction & 22 & 0.0072 & 0.0850 & -0.0074 \\
Coke, Refined Petroleum Prod. & 23 & 0.0126 & 0.1121 & 0.0067 \\
Chemicals And Chemical Products & 24 & 0.0067 & 0.0816 & 0.0124 \\
Rubber And Plastic Products & 25 & 0.0111 & 0.1055 & 0.0084 \\
Other Non-metallic Mineral Products & 26 & 0.0018 & 0.0425 & -0.0006 \\
Basic Metals & 27 & 0.0085 & 0.0921 & 0.0263 \\
Fabricated Metal Prod., Ex. Machinery & 28 & 0.0043 & 0.0657 & 0.0165 \\
Machinery And Equipment NEC & 29 & 0.0054 & 0.0732 & 0.0021 \\
Office Machinery And Computers & 30 & 0.0278 & 0.1667 & -0.0036 \\
Electrical Machinery And Apparatus & 31 & 0.0048 & 0.0690 & -0.0020 \\
Radio, Television And Communication & 32 & 0.0029 & 0.0538 & 0.0028 \\
Medical, Precision And Optical Instr. & 33 & 0.0056 & 0.0751 & 0.0089 \\
Motor Vehicles, Trailers & 34 & 0.0071 & 0.0842 & 0.0003 \\
Other Transport Equipment & 35 & 0.0099 & 0.0994 & -0.0051 \\
Furniture; Manufacturing NEC & 36 & -0.0006 & & -0.0032 \\
\hline
\end{tabular}

Notes Values for income risk are averages over time. Changes are first-to-last period differences of absolute values. The employment weighted industry average (excl. Tobacco) is $7,7 \%\left(\overline{\hat{\sigma}}_{\eta, j}=\right.$ 0.077).Industry names may be incomplete.

\subsection{Measuring the offshoring intensity}

Offshoring is measured using input-output tables and trade data following a method introduced by Feenstra \& Hanson (1996) and extended by Geishecker (2006). The offshoring intensities are calculated to represent the amount of an industry's intermediate inputs purchased from the same industry abroad in total industry output. This emphasizes the fact that the product could have likely been produced at home as well, and precludes situations in which traditionally imported 
Table 2: Descriptives: income risk, BA-panel

\begin{tabular}{lrrrr}
\hline Industry & Code & $\hat{\sigma}_{\eta, j}^{2}$ & $\hat{\sigma}_{\eta, j}$ & Change $\left(\hat{\sigma}_{\eta, j}^{2}\right)$ \\
\hline Food Products And Beverages & 15 & 0.0037 & 0.0607 & 0.0008 \\
Textiles & 17 & 0.0043 & 0.0657 & -0.0007 \\
Wearing Apparel; Dressing And Dyeing & 18 & 0.0041 & 0.0639 & 0.0069 \\
Wood Products, Except Furniture & 20 & 0.0026 & 0.0514 & 0.0074 \\
Pulp, Paper And Paper Products & 21 & 0.0028 & 0.0526 & -0.0031 \\
Publishing, Printing And Reproduction & 22 & 0.0044 & 0.0664 & -0.0023 \\
Chemicals And Chemical Products & 24 & 0.0025 & 0.0501 & 0.0014 \\
Rubber And Plastic Products & 25 & 0.0038 & 0.0619 & -0.0010 \\
Other Non-metallic Mineral Products & 26 & 0.0031 & 0.0559 & 0.0041 \\
Basic Metals & 27 & 0.0030 & 0.0550 & -0.0015 \\
Fabricated Metal Prod., Ex. Machinery & 28 & 0.0042 & 0.0649 & -0.0009 \\
Machinery And Equipment NEC & 29 & 0.0035 & 0.0594 & -0.0003 \\
Office Machinery And Computers & 30 & 0.0057 & 0.0754 & -0.0129 \\
Electrical Machinery And Apparatus & 31 & 0.0034 & 0.0584 & -0.0019 \\
Radio, Television And Communication & 32 & 0.0041 & 0.0638 & 0.0028 \\
Medical, Precision And Optical Instr. & 33 & 0.0035 & 0.0588 & 0.0017 \\
Motor Vehicles, Trailers & 34 & 0.0023 & 0.0483 & 0.0011 \\
Other Transport Equipment & 35 & 0.0030 & 0.0544 & 0.0015 \\
Furniture; Manufacturing NEC & 36 & 0.0041 & 0.0644 & 0.0006 \\
\hline
\end{tabular}

Notes Values for income risk are averages over time. Changes are first-to-last period differences of absolute values. The employment weighted industry average is $5.8 \%\left(\overline{\hat{\sigma}}_{\eta, j}=0.058\right)$.Industry names may be incomplete. 
goods count as offshoring. The offshoring intensity therefore is assumed to describe the outcome of multiple firm's make-or-buy decisions aggregated to the industry level. Note that it captures offshoring that occurs within as well as outside of a firm. In terms of the original notation introduced by Feenstra \& Hanson (1996) our measure is the offshoring intensity in a "narrow" sense. Technically it looks as follows:

$$
O F F_{j t}=\frac{I M P_{j^{*} t} \times \Omega_{j^{*} j t}}{Y_{j t}}
$$

$Y_{j t}$ is output of $j$ at time $t . \Omega_{j^{*} j t}$ describes the share of imports from a specific 2-digit NACE industry $\left(j^{*}\right)$ abroad used in the respective industry $(j)$ at home. These shares are derived from yearly import matrices that are part of the input-output tables provided by the Statistical Office in Germany. ${ }^{19} I M P_{j^{*} t}$ are imports from the foreign industry $j^{*}$, taken from the OECD STAN database. The data on imports and industry output are deflated using an aggregate manufacturing import price deflator and industry-specific producer price indices, respectively. This deflation strategy may be problematic, however, if industry-level import prices deviate strongly from the average. Consider, for example, a situation in which the import price falls strongly for a certain industry. This fall will not be adequately captured by the average import price index which will be "too high". Yet, to the extent that the same price trends are also present in the producer prices, where they are adequately represented due to the more disaggregated indices, there will be an "asymmetric" deflation that by itself raises the offshoring intensity. In the subsequent estimations we therefore also check whether deflating all variables with aggregate indices affects the results.

We furthermore differentiate between worldwide offshoring and offshoring to non-OECD countries. Here we again draw on the OECD STAN database and multiply the imports in (11) by the share of imports coming from non-OECD countries. ${ }^{20}$ Note that this region-specific

\footnotetext{
${ }^{19}$ For the years prior to 1995 those tables are not comparable to the more recent ones due to data revisions. For those years we keep $\Omega_{j^{*} j t}$ constant at its 1995 value - a strategy commonly employed in the literature whenever yearly I-O tables are not available, see e.g. (Hijzen \& Swaim 2010).

${ }^{20}$ When calculating import shares for non-OECD countries, we had to aggregate industries $15-16 ; 17-19$ and 21-22. Note, however, that this only applies to the non-OECD trade share and neither to total imports nor $\Omega_{j^{*} j t}$.
} 
calculation of offshoring entails the common assumption of identical $\Omega_{j^{*} j t}$ for the two groups of countries, since the input-output tables do not hold any region specific information. The special distinction of non-OECD offshoring is meant to reflect the cost savings motive inherent in offshoring - a concept at the core of most theoretical approaches as well as the common public worries.

Table 3 shows offshoring intensities for the different manufacturing industries. Overall, worldwide offshoring has reached significantly higher levels than offshoring to low-income countries. Yet, starting from low values, growth is much stronger for offshoring to non-OECD countries where intensities have more than doubled in 9 industries. Additionally, we observe positive growth in all industries but tobacco as well as coke and refined petroleum for non-OECD offshoring, while only about two thirds of the industries had a higher worldwide offshoring intensity in 2005 compared to 1991. Interestingly, for both measures the industries show quite some heterogeneity with respect to variations over time. This variation will be important in identifying the effect of offshoring on income risk later on.

\section{Econometric specification}

We now turn to developing a suitable estimation strategy for an evaluation of the impact of offshoring on income risk. The data at hand permits a panel approach controlling for unobserved heterogeneity in two dimensions: industry and time. Industry-specific effects may well matter for the relationship between offshoring and income risk. Some industries are probably more inherently risky than others. This may be due to different demand elasticities for their products or unique employment structures in terms of jobs and tasks that can differ in their idiosyncratic risk. As long as these characteristics are specific to an industry and do not vary over time, a fixed-effects setup will capture this type of unobserved heterogeneity. For timevarying coefficients that are unobservable to us, such as business cycle effects at the country or world level, we can employ time fixed-effects which capture this variation as long as it is uniform across industries. All remaining variation will have to be picked up by the variables included in the model. These will naturally be measures for offshoring along with controls for technological 
Table 3: Offshoring - descriptives

\begin{tabular}{|c|c|c|c|c|c|c|c|}
\hline \multirow[b]{2}{*}{ Industry } & \multirow[b]{2}{*}{ Code } & \multicolumn{3}{|c|}{ worldwide } & \multicolumn{3}{|c|}{ non-OECD } \\
\hline & & 1991 & 2005 & change & 1991 & 2005 & change \\
\hline Food Products And Beverages & 15 & 3.85 & 3.97 & 0.12 & 0.61 & 0.63 & $\overline{0.02}$ \\
\hline Tobacco & 16 & 1.00 & 0.88 & -0.13 & 0.16 & 0.14 & -0.02 \\
\hline Textiles & 17 & 10.70 & 8.79 & -1.91 & 3.95 & 4.42 & 0.47 \\
\hline Wearing Apparel; Dressing & 18 & 12.13 & 12.94 & 0.81 & 4.48 & 6.51 & 2.03 \\
\hline Tanning And Dressing of Leather, & 19 & 19.30 & 18.19 & -1.11 & 7.13 & 9.15 & 2.02 \\
\hline Wood Products, Except Furniture & 20 & 4.73 & 3.49 & -1.24 & 1.06 & 1.11 & 0.06 \\
\hline Pulp, Paper And Paper Products & 21 & 9.87 & 8.87 & -1.01 & 0.40 & 0.54 & 0.15 \\
\hline Publishing, Printing & 22 & 0.47 & 0.92 & 0.45 & 0.02 & 0.06 & 0.04 \\
\hline Coke, Refined petroleum & 23 & 3.12 & 3.33 & 0.21 & 0.56 & 0.45 & -0.10 \\
\hline Chemicals And Chemical Produ & 24 & 11.77 & 13.73 & 1.96 & 0.81 & 0.98 & 0.18 \\
\hline Rubber And Plastic Products & 25 & 1.05 & 1.48 & 0.43 & 0.08 & 0.19 & 0.12 \\
\hline Other Non-metallic Mineral Products & 26 & 2.36 & 2.08 & -0.28 & 0.27 & 0.34 & 0.07 \\
\hline Basic Metals & 27 & 12.65 & 16.35 & 3.70 & 2.19 & 3.36 & 1.17 \\
\hline Fabricated Metal Prod., excl. Mach. & 28 & 1.15 & 1.81 & 0.66 & 0.23 & 0.37 & 0.15 \\
\hline Machinery And Equipment NEC & 29 & 4.48 & 7.35 & 2.86 & 0.54 & 1.94 & 1.40 \\
\hline Office Machinery And Computers & 30 & 16.60 & 13.85 & -2.75 & 2.51 & 6.06 & 3.56 \\
\hline Electrical Machinery & 31 & 2.84 & 6.57 & 3.73 & 0.39 & 1.52 & 1.13 \\
\hline Radio, Television, Communication & 32 & 17.67 & 19.75 & 2.07 & 3.33 & 6.99 & 3.66 \\
\hline Medical, Precision And Optical & 33 & 2.52 & 4.52 & 2.01 & 0.25 & 0.71 & 0.46 \\
\hline Motor Vehicles, Trailers & 34 & 12.71 & 10.21 & -2.49 & 0.39 & 0.55 & 0.16 \\
\hline Other Transport Equipm & 35 & 10.12 & 13.03 & 2.91 & 0.37 & 1.18 & 0.81 \\
\hline Furniture; Manufacturing NEC & 36 & 2.21 & 9.42 & 7.20 & 0.61 & 3.81 & 3.20 \\
\hline
\end{tabular}

Notes: Values are calculated according to $O F F_{j t}=\frac{I M P_{j^{*} t} \times \Omega_{j^{*} j t}}{Y_{j t}}$ and represent percentage values. Changes are absolute changes. 
change, and other time-varying industry specific variables. We will specify the exact nature of the control vector further below. At this point it is sufficient to state that identification of the effect of offshoring on income risk will be based on differential movements in industry-level offshoring over time. A further point deserves attention. Given the structure of our data set, we have to be careful when calculating standard errors (Krebs et al. 2010). Our dependent variable $\sigma_{\eta j t}^{2}$ is by itself the outcome of an estimation at the industry level. With different standard errors across industries from the first-stage estimations, we are facing heteroscedasticity. Furthermore, there is the possibility of serial dependence of error terms within industries. We therefore follow the literature in reporting robust standard errors. ${ }^{21}$

With the above considerations in mind, we arrive at the following empirical models, where the first one is applied to the long-run data set based on $m$-year average values and the second model is used in the analysis of the yearly data. Importantly, this latter model also allows for the inclusion of lagged effects of offshoring on income risk if we chose $N>0$ :

$$
\begin{gathered}
\sigma_{\eta j m}^{2}=\beta_{1} O F F_{j m}+\gamma X_{j m}+\phi_{j}+\varphi_{m}+\nu_{j m} \\
\sigma_{\eta j t}^{2}=\Sigma_{i=0}^{N} \beta_{i} O F F_{j t-i}+\gamma X_{j t}+\phi_{j}+\varphi_{t}+\nu_{j t}
\end{gathered}
$$

In these models, the control vector $X_{j t}$ holds a variable approximating technological progress using the share of $\mathrm{R} \& \mathrm{D}$ expenditure in industry value-added as suggested by the literature. Country-wide trends in technology upgrading that are unrelated to offshoring but impact on income risk are picked up by the year effects. Furthermore, it includes measures for the exportshare in production (capturing another dimension of dependency on international output fluctuations), the import penetration ratio (to provide for a comparison with the literature - Krishna \& Senses (2009) in particular), and the industry level labor share of income (meant to broadly capture the influence of labor market institutions on income risk). ${ }^{22}$ In addition we use different measures for the offshoring intensity based on an alternative deflation strategy (using aggregate

\footnotetext{
${ }^{21}$ Krebs et al. (2010) state that the dependent variable being the outcome of an estimation does not introduce a bias in the coefficient estimates while standard errors have to be adjusted.

${ }^{22}$ All these data are retrieved from the OECD STAN database.
} 
price indices for both imports and output) and differentiate between worldwide offshoring and offshoring to non-OECD countries, the latter again based on the standard deflation procedure. In both cases $\phi_{j}$ represents the industry fixed-effects. $\varphi_{m}$ and $\varphi_{t}$ are binary variables for 5-year periods $(m)$ and years $(t)$, respectively. $\nu_{j m}$ and $\nu_{j t}$ represent the two model's error terms.

\section{Results: offshoring lowers income risk.}

In this subsection we present the results based on the above models. We begin with a discussion of model (12)'s results and subsequently turn to estimating equation (13).

Table 4 has a clear message: an increase in offshoring correlates with lower permanent income risk. We find negative coefficients on the different offshoring variables throughout columns (1) to (6) in table 4 . The results are always statistically significant at conventional levels. The coefficient value in column (1) implies that, on average, an increase in the offshoring intensity by one percentage point - which is close to but a little lower than the actual observed change in aggregate manufacturing offshoring of about 1.3 percentage points - decreases the permanent component of income risk by -0.00131 . Compared to its (employment weighted) mean across industries and over time of 0.0060 , this represents a decrease of more than $20 \%$ for every percentage point increase in the overall offshoring intensity. The effect is stronger for offshoring to non-OECD countries. The results in column (3) show the effect to be roughly three times the size of the corresponding value for worldwide offshoring. This type of offshoring, however, shows a smaller absolute increase over time; roughly half a percentage point.

Including a number of industry-level control variables leaves the main message untouched. Offshoring is still a negative and significant influence on permanent income risk. Yet, the coefficients of the control variables hold a small bit of additional information. The import penetration ratio is found to increase income risk. A finding which weakly confirms the result found in $\mathrm{Kr}$ ishna \& Senses (2009) for the US also for Germany. The labor share on the other hand correlates negatively with permanent income risk. This potentially expresses the influence labor market institutions and union presence have in smoothing the long-run income path. The R\&D share 
does not have any significant effects. It seems as if this variable is unable to approximate technological change above common aggregate-level trends captured by the time effects. Overall, the above results suggest that offshoring-induced structural change within manufacturing - with an ever higher share of tasks located abroad - is associated with a decrease in income risk.

Table 4: Results based on 5-year averages, 1991-2005

\begin{tabular}{|c|c|c|c|c|c|c|}
\hline income risk (permanent component) & 1 & 2 & 3 & 4 & 5 & 6 \\
\hline offshoring intensity (world) & $\begin{array}{c}-0.131^{* *} \\
(0.0586)\end{array}$ & & & $\begin{array}{c}-0.179 * * \\
(0.0659)\end{array}$ & & \\
\hline offshoring intensity (world; alt. defl.) & & $\begin{array}{c}-0.105^{*} \\
(0.0585)\end{array}$ & & & $\begin{array}{c}-0.139^{* *} \\
(0.0653)\end{array}$ & \\
\hline offshoring intensity (non-OECD) & & & $\begin{array}{r}-0.350^{* *} \\
(0.165)\end{array}$ & & & $\begin{array}{c}-0.379^{*} \\
(0.213)\end{array}$ \\
\hline export-share in production & & & & $\begin{array}{r}-0.0667 \\
(0.0417)\end{array}$ & $\begin{array}{r}-0.0253 \\
(0.0402)\end{array}$ & $\begin{array}{r}-0.0514 \\
(0.0348)\end{array}$ \\
\hline import penetration & & & & $\begin{array}{r}0.0705 \\
(0.0432)\end{array}$ & $\begin{array}{r}0.0350 \\
(0.0385)\end{array}$ & $\begin{array}{c}0.0674^{*} \\
(0.0375)\end{array}$ \\
\hline $\mathrm{R} \& \mathrm{D}$ share in value added & & & & $\begin{array}{r}0,0070 \\
(0.0346)\end{array}$ & $\begin{array}{r}0.0117 \\
(0.0332)\end{array}$ & $\begin{array}{r}-0,0020 \\
(0.0399)\end{array}$ \\
\hline laborshare & & & & $\begin{array}{c}-0.0293^{*} \\
(0.0162)\end{array}$ & $\begin{array}{r}-0.0276 \\
(0.0180)\end{array}$ & $\begin{array}{r}-0.0290^{*} \\
(0.0165)\end{array}$ \\
\hline time-period fixed-effects & yes & yes & yes & yes & yes & yes \\
\hline industry fixed-effects & yes & yes & yes & yes & yes & yes \\
\hline Observations & 66 & 66 & 66 & 63 & 63 & $\overline{63}$ \\
\hline R-squared & 0.186 & 0.200 & 0.181 & 0.288 & 0.232 & 0.287 \\
\hline Number of industries & 22 & 22 & 22 & 21 & 21 & 21 \\
\hline
\end{tabular}

Notes: Estimation is by fixed-effects. The coefficient values on the offshoring measures are to be understood as follows: a one unit change in offshoring (= percentage point change) corresponds to a $\hat{\beta} / 100$ change in the variance of persistent changes in the unexplained component of income (= permanent income risk). Industry 36 has incomplete data coverage which leads to a slightly reduced number of observations in some cases. Robust standard errors are shown in parentheses; *** $\mathrm{p}<0.01,{ }^{* *} \mathrm{p}<0.05,{ }^{*} \mathrm{p}<0.1$.

In table 5, we turn to the results based on model (13) using yearly data. Again, we find average permanent income risk to be reduced by an increase in offshoring. We present results for one-year lagged values of offshoring as explanatory variables, because we do not find any significant contemporaneous correlation. This points to the impact offshoring has on income risk as the outcome of a change in how employment and production are organized internationally. Recall, that income risk measures shocks from an ex-ante perspective, i.e. it describes how 
shocks at a given time play out over future periods. We can therefore state that, on average, workers in an industry that shifts more tasks abroad will subsequently face less severe shocks to permanent income. ${ }^{23}$

The coefficient values are somewhat smaller now, thus implying a decrease in income risk of only about $8 \%$ compared to the mean value following an increase in the overall offshoring intensity by one percentage point. The results are not strictly comparable to the ones of model 1 , however, because they are based on different data sets and a different estimation of income risk itself. ${ }^{24}$ Furthermore, for offshoring to non-OECD countries, which again triggers larger coefficients, we also find significant effects of two-year lagged offshoring intensities. ${ }^{25}$ This could point to model 1's results representing a cumulative effect over the multiple-year period. Turning back to the estimates on single period lags, the coefficient for non-OECD offshoring implies roughly a forty percent decrease in permanent income risk for every percentage point increase in offshoring (compared to the mean value of income risk). Note, however, that average offshoring to non-OECD countries grew from $0.8 \%$ to $1.4 \%$ - a change of a little more than half a percentage point. With respect to the control variables, not much seems to be gained from their inclusion. None of them have a significant impact, although the labor share and the import penetration ratio show the same sign as in table 4 . In summary, our results from both models show a negative and significant effect of offshoring on the permanent component of income risk. Offshoring to non-OECD countries has a particularly strong effect.

\footnotetext{
${ }^{23}$ This does not say anything about the possible effects of displacements at the margin of offshoring. Yet, according to some recent studies, offshoring does not seem to be a major cause of overall job-loss at the industry level (OECD 2007, Harrison \& McMillan 2011).

${ }^{24}$ Furthermore, the BA-panel data do not allow us to estimate income risk for manufacturing industries 19 and 23, which turn out to be marked by particularly high levels of income risk. Excluding those industries in the estimation of model 1 lowers the coefficient on the offshoring variable and brings it closer to the values obtained from model 2 .

${ }^{25}$ The results are not shown in the present table for the sake of expositional clarity. The coefficient value for 2-year lagged non-OECD offshoring is -.11 with a robust standard error of .062 for the model including all controls.
} 
Table 5: Results based yearly data, 1999-2005

\begin{tabular}{|c|c|c|c|c|c|c|}
\hline income risk (permanent component) & 1 & 2 & 3 & 4 & 5 & 6 \\
\hline 1-year lagged offshoring intensity (world) & $\begin{array}{c}-0.0282^{*} \\
(0.0148)\end{array}$ & & & $\begin{array}{c}-0.0278^{*} \\
(0.0139)\end{array}$ & & \\
\hline 1-year lagged offshoring intensity (world; alt. defl.) & & $\begin{array}{c}-0.0344^{*} \\
(0.0188)\end{array}$ & & & $\begin{array}{c}-0.0291^{*} \\
(0.0144)\end{array}$ & \\
\hline 1-year lagged offshoring intensity (non-OECD) & & & $\begin{array}{c}-0.145^{*} \\
(0.0715)\end{array}$ & & & $\begin{array}{c}-0.120^{* *} \\
(0.0552)\end{array}$ \\
\hline export-share in production & & & & $\begin{array}{c}-0.0314^{*} \\
(0.0180)\end{array}$ & $\begin{array}{r}-0.0291 \\
(0.0168)\end{array}$ & $\begin{array}{r}-0.0275 \\
(0.0174)\end{array}$ \\
\hline import penetration & & & & $\begin{array}{r}0.0227 \\
(0.0197)\end{array}$ & $\begin{array}{r}0.0226 \\
(0.0190)\end{array}$ & $\begin{array}{r}0.0218 \\
(0.0197)\end{array}$ \\
\hline $\mathrm{R} \& \mathrm{D}$ share in value added & & & & $\begin{array}{r}0.0162 \\
(0.0179)\end{array}$ & $\begin{array}{r}0.0104 \\
(0.0152)\end{array}$ & $\begin{array}{r}0,0044 \\
(0.0136)\end{array}$ \\
\hline laborshare & & & & $\begin{array}{r}0.00109 \\
(0.00741)\end{array}$ & $\begin{array}{r}0.00232 \\
(0.00687)\end{array}$ & $\begin{array}{r}0.00289 \\
(0.00623)\end{array}$ \\
\hline year fixed-effects & yes & yes & yes & yes & yes & $\overline{\text { yes }}$ \\
\hline industry fixed-effects & yes & yes & yes & yes & yes & yes \\
\hline Observations & 114 & 114 & 114 & 108 & 108 & 108 \\
\hline R-squared & 0.189 & 0.263 & 0.308 & 0.364 & 0.388 & 0.409 \\
\hline Number of industries & 19 & 19 & 19 & 18 & 18 & 18 \\
\hline
\end{tabular}

Notes: Estimation is by fixed-effects. The coefficient values on the offshoring measures are to be understood as follows: a one unit change in offshoring (= percentage point change) corresponds to a $\hat{\beta} / 100$ change in the variance of persistent changes in the unexplained component of income (= permanent income risk). Industry 36 has incomplete data coverage which leads to a slightly reduced number of observations in some cases. Robust standard errors are shown in parentheses; ${ }^{* * *} \mathrm{p}<0.01,{ }^{* *} \mathrm{p}<0.05,{ }^{*} \mathrm{p}<0.1$. 


\section{Concluding remarks}

The analysis in this paper presents offshoring as a source of changes in permanent income risk. Income risk is an important factor in determining the consumption, savings and thus welfare patterns in an economy. We single out offshoring as a potential influence given the anxiety it regularly stirs up in the public debate as well as its large role in international trade transactions. Within the limits of our available data, we seeks to answer whether the fears regarding income insecurity often associated with it are justified. We find that they are not. On the contrary, within manufacturing industries, increased offshoring is associated with a decrease in the permanent component of income risk.

In our empirical analysis, we first estimate industry-level income risk from individual level data, isolating the welfare-relevant permanent component for two different data-sets. We then link it to offshoring at the industry level in a panel framework. We find offshoring to have a negative and statistically significant effect on income risk for employees within industries in manufacturing. Furthermore, there is strong evidence for a differentiated impact across destination regions, with a stronger than average effect for offshoring to non-OECD countries. This is expected as offshoring in this case is closer to a process of wage related labor substitution in an ongoing reallocation of different tasks around the globe.

However, with respect to welfare implications the results are less straight forward. Clearly, taken by itself, a reduction in income risk brought about by a higher offshoring intensity would imply a positive welfare effect. Yet, this effect might not be the only welfare-affecting change. Two points deserve particular attention. First, the wage level still matters as well. Individuals may have a smaller benefit if risk decreases but this comes as a trade-off with lower average wages. Yet, on an aggregate level, this is not necessarily to be expected. Grossman \& Rossi-Hansberg (2008) theoretically show that the wage effects of offshoring are ambiguous, and empirical evidence often documents relative wages for different skill groups to change while overall wages are hardly affected. Leaving considerations with respect to a skill-specific effect to further research, we are therefore leaning towards the conclusion that lower income risk does not come at the cost 
of lower average wages in manufacturing.

The second possible concern is related to employment levels. A shift of more volatile occupations (or tasks) abroad may change average income risk in the home country at the expense of lower overall employment levels. The volatile jobs would move offshore and - as a consequence the remaining ones show a lower average income risk. Yet, it is hard to argue that this situation is desirable from an aggregate perspective if overall employment falls. Ideally, if composition effects are at work, one would want the home employment to stay constant or to grow due to productivity effects from offshoring and the workers whose tasks are moved offshore would find re-employment in less volatile jobs. There are some hints that offshoring is not responsible for falling employment levels in manufacturing. For instance, the OECD states that " (...) the industrial sectors that have most downsized their workforce are not the ones that have most engaged in offshoring. Offshoring does not therefore emerge as a major cause of job losses." (OECD 2007). This finding has recently been confirmed by Harrison \& McMillan (2011) for the United States, who find most of the manufacturing employment decline to be a result of capital-labor substitution rather than international labor reallocation. We therefore conclude on a slightly optimistic tone. If offshoring lowers the permanent component of income risk, while average wages do not fall and overall employment stays widely unaffected, there may be positive effects on welfare. 


\section{References}

Aiyagari, S. (1994), 'Uninsured idiosyncratic risk and aggregate saving', The Quarterly Journal of Economics 109(3), 659-684.

Altonji, J. \& Segal, L. (1996), 'Small-sample bias in gmm estimation of covariance structures', Journal of Business \& Economic Statistics 14(3), 353-366.

Becker, S. \& Muendler, M. (2008), 'The Effect of FDI on Job Security', The BE Journal of Economic Analysis 83 Policy 8(1), Article 8.

Bergin, P., Feenstra, R. \& Hanson, G. (2009), 'Offshoring and Volatility: Evidence from Mexico's Maquiladora Industry', The American Economic Review 99(4), 1664-1671.

Buch, C. \& Lipponer, A. (2010), 'Volatile multinationals? Evidence from the labor demand of German firms', Labour Economics 17(2), 345-353.

Carroll, C. \& Samwick, A. (1997), 'The nature of precautionary wealth', Journal of Monetary Economics 40(1), 41-71.

Constantinides, G. \& Duffie, D. (1996), 'Asset pricing with heterogeneous consumers', The Journal of Political Economy 104(2), 219-240.

Dustmann, C., Ludsteck, J. \& Schoenberg, U. (2009), 'Revisiting the german wage structure', The Quarterly Journal of Economics 124(2), 843-881.

Feenstra, R. (2010), Offshoring in the global economy: microeconomic structure and macroeconomic implications, The MIT Press.

Feenstra, R. \& Hanson, G. (1996), 'Globalization, outsourcing, and wage inequality', The American Economic Review 86(2), 240-245.

Gartner, H. (2005), 'The imputation of wages above the contribution limit with the german iab employment sample', FDZ Methodenreport 2, 2005.

Geishecker, I. (2006), 'Does outsourcing to Central and Eastern Europe really threaten manual workers' jobs in Germany?', World Economy 29(5), 559-583. 
Gottschalk, P. \& Moffitt, R. (1994), 'The growth of earnings instability in the US labor market', Brookings Papers on Economic Activity 1994(2), 217-272.

Grossman, G. \& Rossi-Hansberg, E. (2008), 'Trading tasks: a simple theory of offshoring', The American Economic Review 98(5), 1978-1997.

Harrison, A. \& McMillan, M. (2011), 'Offshoring jobs? multinationals and us manufacturing employment', The Review of Economics and Statistics 93(3), 857-875.

Hijzen, A. \& Swaim, P. (2010), 'Offshoring, labour market institutions and the elasticity of labour demand', European Economic Review 54(8), 1016-1034.

Kohler, W. \& Wrona, J. (2010), 'Offshoring Tasks, yet Creating Jobs?', CESifo Working Paper Series 3019.

Krebs, T. (2003), 'Human Capital Risk and Economic Growth', The Quarterly Journal of Economics 118(2), 709-744.

Krebs, T., Krishna, P. \& Maloney, W. (2010), 'Trade policy, income risk, and welfare', The Review of Economics and Statistics 92(3), 467-481.

Krishna, P. \& Senses, M. (2009), 'International trade and labor income risk in the United States', NBER Working Paper (14992).

Levine, D. \& Zame, W. (2002), 'Does market incompleteness matter?', Econometrica 70(5), 1805-1839.

Meghir, C. \& Pistaferri, L. (2004), 'Income variance dynamics and heterogeneity', Econometrica 72(1), 1-32.

OECD (2007), 'Offshoring and Employment: Trends and Impacts', OECD Report .

Schmucker, A. \& Seth, S. (2009), 'Ba-employment panel 1998-2007, codebook (only in german)', FDZ Datenreport 1.

Senses, M. (2010), 'The effects of offshoring on the elasticity of labor demand', Journal of International Economics 81(1), 89-98. 
Storesletten, K., Telmer, C. \& Yaron, A. (2004), 'Cyclical dynamics in idiosyncratic labor market risk', Journal of Political Economy 112(3), 695-717.

Wagner, G. G., Frick, J. R. \& Schupp, J. (2007), 'The german socio-economic panel study (soep) - scope, evolution and enhancements', Schmollers Jahrbuch 127(1), 139-169. 


\section{Appendix}

This first additional table (6) shows results from the first stage regression generating the income residuals. Coefficients on industry fixed-effects are not shown. The results are based on BA data with imputed wages from the cross section for the year 2005. Results for any other year virtually look the same. All coefficients have the expected sign and significance. That is, income grows with age, skill, firm size, etc.

Table 6: First stage wage regression for 2005

\begin{tabular}{lc}
\hline ln wage & 1 \\
\hline age & $0.00893^{* * *}$ \\
foreign nationality & $(0.000101)$ \\
& $\left(0.0984^{* * *}\right.$ \\
firm size & $0.0532^{* * *}$ \\
& $(0.000612)$ \\
medium skilled & $0.218^{* * *}$ \\
& $(0.00517)$ \\
highly skilled & $0.480^{* * *}$ \\
& $(0.00324)$ \\
constant & $7.169^{* * *}$ \\
& $(0.00661)$ \\
& \\
\hline industry fixed effects & yes \\
\hline Observations & 72,904 \\
R-squared & 0.461 \\
\hline
\end{tabular}

The following table 7 provides results from using BA data from the June waves only. As in all previous tables, offshoring is associated with a decrease in permanent income risk.

In table 8 we address the concern of some income risk estimates being individually insignificant when using SOEP data. (With the BA data we do not face this problem to any comparable extent.) We simply drop these observations and re-run the regressions. We still find increased offshoring to be associated with a decrease in permanent income risk. 
Table 7: Results based yearly data, 1999-2005, June waves only

\begin{tabular}{|c|c|c|c|c|c|c|}
\hline income risk (permanent component) & 1 & 2 & 3 & 4 & 5 & 6 \\
\hline 1-year lagged offshoring intensity (world) & $\begin{array}{c}-0.0107^{* *} \\
(0.00470)\end{array}$ & & & $\begin{array}{r}-0.00849 \\
(0.00677)\end{array}$ & & \\
\hline 1-year lagged offshoring intensity (world; alt. defl.) & & $\begin{array}{r}-0.0199^{* * *} \\
(0.00559)\end{array}$ & & & $\begin{array}{c}-0.0121^{* *} \\
(0.00421)\end{array}$ & \\
\hline 1-year lagged offshoring intensity (non-OECD) & & & $\begin{array}{r}-0.0707^{* * *} \\
(0.0222)\end{array}$ & & & $\begin{array}{r}-0.0322 \\
(0.0189)\end{array}$ \\
\hline export-share in production & & & & $\begin{array}{r}-0.0383 \\
(0.0228)\end{array}$ & $\begin{array}{r}-0.0378 \\
(0.0226)\end{array}$ & $\begin{array}{r}-0.0371 \\
(0.0233)\end{array}$ \\
\hline import penetration & & & & $\begin{array}{r}0.0280 \\
(0.0248)\end{array}$ & $\begin{array}{r}0.0288 \\
(0.0244)\end{array}$ & $\begin{array}{r}0.0275 \\
(0.0254)\end{array}$ \\
\hline $\mathrm{R} \& \mathrm{D}$ share in value added & & & & $\begin{array}{r}0.0128 \\
(0.0146)\end{array}$ & $\begin{array}{r}0.0110 \\
(0.0146)\end{array}$ & $\begin{array}{r}0,0094 \\
(0.0157)\end{array}$ \\
\hline laborshare & & & & $\begin{array}{r}0,00007 \\
(0.00576)\end{array}$ & $\begin{array}{r}0.000871 \\
(0.00537)\end{array}$ & $\begin{array}{r}0.000451 \\
(0.00594)\end{array}$ \\
\hline year fixed-effects & yes & yes & yes & yes & yes & yes \\
\hline industry fixed-effects & yes & yes & yes & yes & yes & yes \\
\hline Observations & 114 & 114 & 114 & 108 & 108 & 108 \\
\hline R-squared & 0.085 & 0.133 & 0.126 & 0.332 & 0.344 & 0.334 \\
\hline Number of industries & 19 & 19 & 19 & 18 & 18 & 18 \\
\hline
\end{tabular}

Notes: Estimation is by fixed-effects. The coefficient values on the offshoring measures are to be understood as follows: a one unit change in offshoring (= percentage point change) corresponds to a $\hat{\beta} / 100$ change in the variance of persistent changes in the unexplained component of income (= permanent income risk). Industry 36 has incomplete data coverage which leads to a slightly reduced number of observations in some cases. Robust standard errors are shown in parentheses; $* * * \mathrm{p}<0.01, * * \mathrm{p}<0.05, * \mathrm{p}<0.1$. 
Table 8: Results for 5-year averages, 1991-2005, individually significant risk estimates only

\begin{tabular}{|c|c|c|c|c|c|c|}
\hline income risk (permanent component) & 1 & 2 & 3 & 4 & 5 & 6 \\
\hline offshoring intensity (world) & $\begin{array}{r}-0.187 \\
(0.126)\end{array}$ & & & $\begin{array}{r}-0.235^{* * *} \\
(0.0531)\end{array}$ & & \\
\hline offshoring intensity (world; alt. defl.) & & $\begin{array}{r}-0.180 \\
(0.131)\end{array}$ & & & $\begin{array}{r}-0.241^{* * *} \\
(0.0554)\end{array}$ & \\
\hline offshoring intensity (non-OECD) & & & $\begin{array}{r}-0.421^{* * *} \\
(0.132)\end{array}$ & & & $\begin{array}{r}-0.508^{* *} \\
(0.217)\end{array}$ \\
\hline export-share in production & & & & $\begin{array}{c}0.00805 \\
(0.0581)\end{array}$ & $\begin{array}{r}0.00430 \\
(0.0585)\end{array}$ & $\begin{array}{r}0.0658 \\
(0.0545)\end{array}$ \\
\hline import penetration & & & & $\begin{array}{r}0.00191 \\
(0.107)\end{array}$ & $\begin{array}{r}0.00820 \\
(0.107)\end{array}$ & $\begin{array}{r}-0.0600 \\
(0.0960)\end{array}$ \\
\hline $\mathrm{R} \& \mathrm{D}$ share in value added & & & & $\begin{array}{c}-0.00194^{* *} \\
(0.000896)\end{array}$ & $\begin{array}{c}-0.00208^{* *} \\
(0.000901)\end{array}$ & $\begin{array}{r}-0.000936 \\
(0.000966)\end{array}$ \\
\hline laborshare & & & & $\begin{array}{r}-0.0621 \\
(0.0602)\end{array}$ & $\begin{array}{r}-0.0617 \\
(0.0597)\end{array}$ & $\begin{array}{r}-0.0596 \\
(0.0682)\end{array}$ \\
\hline time-period fixed-effects & yes & yes & yes & yes & yes & yes \\
\hline industry fixed-effects & yes & yes & yes & yes & yes & yes \\
\hline Observations & 27 & 27 & 27 & 27 & 27 & 27 \\
\hline R-squared & 0.338 & 0.330 & 0.240 & 0.611 & 0.615 & 0.525 \\
\hline Number of industries & 15 & 15 & 15 & 15 & 15 & 15 \\
\hline
\end{tabular}

Notes: Estimation is by fixed-effects. The coefficient values on the offshoring measures are to be understood as follows: a one unit change in offshoring (= percentage point change) corresponds to a $\hat{\beta} / 100$ change in the variance of persistent changes in the unexplained component of income (= permanent income risk). Industry 36 has incomplete data coverage which leads to a slightly reduced number of observations in some cases. Robust standard errors are shown in parentheses; ${ }^{* * *} \mathrm{p}<0.01,{ }^{* *} \mathrm{p}<0.05,{ }^{*} \mathrm{p}<0.1$. 